\title{
Vegetation Database of Sudost-Desna Interfluve Area
}

\author{
Yury Semenishchenkov
}

Abstract: The Vegetation Database of Sudost-Desna Interfluve Area (GIVD ID EU-RU-008) contains relevés collected in 2002-2009 in the interfluve area of Sudost and Desna rivers in the Bryansk region. This territory is situated on the central part of the Russian plain in South-Western Nechernozemje. The relevés present broad-leaved, spruce-broad-leaved and pine forests, grasslands and marshland vegetation. The database is developed by the Department of Botany of Bryansk State University (Bryansk, Russia).

Keywords: forest; grassland; marshland; Russian plain; South-Western Nechernozemje.

GIVD Database ID: EU-RU-008

Vegetation Database of Sudost-Desna Interfluve Area

Scope: Releves of the wood, grass and marsh vegetation of the Sudost-Desna interfluve area, located in the central part of the Bryansk region (the central part of the Russian plain)

Status: completed and continuing

Period: 2002-2009

Database manager(s): Yury Semenishchenkov (yuricek@yandex.ru)

Owner: Yury Semenishchenkov (private)

Web address: http://www.brgu.ru/kafedra_botaniki/

Availability: according to a specific agreement

Database format(s): TURBOVEG, Excel

Online upload: no

Online search: no

Publication: [NA]

Plot type(s): normal plots

Export format(s): TURBOVEG, Excel, CSV file

Non-overlapping plots: 2,000

Plot-size range: $1-400 \mathrm{~m}^{2}$

Total plot observations: 2,000

Estimate of existing plots: [NA]

Number of sources: 1

Completeness: [NA]

Countries: RU: $100.0 \%$

Forest: [NA] - Non-forest: [NA]

Guilds: all vascular plants: $100 \%$; bryophytes (terricolous or aquatic): $100 \%$

Environmental data: altitude: $100 \%$; slope inclination: $100 \%$; soil depth: $100 \%$

Performance measure(s): cover: $100 \%$

Geographic localisation: political units or only on a coarser scale (>10 km): $100 \%$

Sampling periods: $2000-2009: 100.0 \%$

Information as of 2012-07-12; further details and future updates available from http://www.givd.info/ID/EU-RU-008

Yury Semenishchenkov (yuricek@yandex.ru)

Department of Botany, Bryansk State University, Bezhitskaya, 14, 241036 Bryansk, RUSSIA 